\title{
IMPRESSION RELAXATION AND CREEP BEHAVIOR OF Al/SiC NANOCOMPOSITE
}

\author{
SPROSTITEV VTISA IN OBNAŠANJE Al/SiC NANOKOMPOZITA \\ PRI LEZENJU
}

\author{
Yasaman Saberi Kakhki, Said Nategh, Tehrani Shamseddin Mirdamadi \\ Islamic Azad University, Tehran Science and Research Branch, Department of Materials Engineering, Tehran, Iran \\ s.nategh@srbiau.ac.ir \\ Prejem rokopisa - received: 2015-06-04; sprejem za objavo - accepted for publication: 2015-08-25
}

doi:10.17222/mit.2015.113

\begin{abstract}
In the present study, Al-4\% of volume fractions of $\mathrm{SiC}$ composites were produced by mechanical alloying and the powders were gradually compacted at a pressure of $620 \mathrm{MPa}$. The post-compaction samples were sintered under an argon atmosphere at $873 \mathrm{~K}$ and the corresponding creep results were obtained from impression-relaxation. Additionally, compression techniques were investigated at high temperature $(723 \mathrm{~K})$. Enforcement rates of $8.3 \times 10^{-3}$ and $0.83 \times 10^{-3} \mathrm{~mm} \mathrm{~s}^{-1}$ and indenter depths of $0.5 \mathrm{~mm}$ and $0.8 \mathrm{~mm}$ were selected. Results showed a constant relation between stress relaxation and compression creep rate. Under different conditions of impression-relaxation this constant was 1000 for compression stress of $30 \mathrm{MPa}$ and $32.5 \mathrm{MPa}$, and 400 for compression stress of $35 \mathrm{MPa}$, subsequently. This coefficient was affected by the porosity and was stable for different indenter depths and enforcement rates. The variations in the steady state relaxation rate were reasonable because of different nano-SiC distributions and porosities in the form of drops. Moreover, in spite of the enforcement rate decrease, the nanosized reinforcing particles caused a decrease of the relaxation rate. It should be mentioned that the constant coefficient calculated will be useful to estimate the fracture time which uses the strain rate calculated from impression-relaxation in industrial applications.

Keywords: Al-SiC, creep, impression relaxation, nanocomposite, powder processing
\end{abstract}

V študiji so bili izdelani kompoziti Al-4 \% volumenskega deleža SiC z mehanskim legiranjem, prahovi pa so bili postopoma stisnjeni do tlaka $620 \mathrm{MPa}$. Stisnjeni vzorci so bili nato sintrani v atmosferi argona na $873 \mathrm{~K}$. Iz sprostitve pri vtiskovanju je bila dobljena povezava z rezultati lezenja. Dodatno so bile preiskovane tehnike stiskanja pri visoki temperaturi (723 K). Izbrani sta bili hitrosti vtiskovanja $8,3 \times 10^{-3} \mathrm{~mm} \mathrm{~s}^{-1}$ kot tudi $0,83 \times 10^{-3} \mathrm{~mm} \mathrm{~s}^{-1}$ pri globini vtiska $0,5 \mathrm{~mm}$ in $0,8 \mathrm{~mm}$. Rezultati so pokazali konstanten koeficient med sprostitvijo napetosti in hitrostjo lezenja pri tlačenju. Vrednost konstante je bila pri različnih pogojih sprostitve vtiska 1000 pri napetostih stiskanja $30 \mathrm{MPa}, 32,5 \mathrm{MPa}$ in 400 pri napetosti stiskanja $35 \mathrm{MPa}$. Na koeficient vpliva tudi poroznost, stabilen pa je pri različnih globinah vtisa in hitrostih vtiskovanja. Tudi rezultati sprostitve so bili občutljivi zaradi različne razporeditve SiC nanodelcev in poroznosti v obliki kapljic. Poleg tega, kljub zmanjševanju hitrosti vtiskovanja nanoutrjevalci zmanjšajo hitrost sprostitve. Pomembno je omeniti, da bo iz hitrosti obremenjevanja in sproščanja pri vtiskovanju izračunani konstantni koeficient uporaben za napovedovanje časa porušitve pri industrijski uporabi.

Ključne besede: Al-SiC, lezenje, sprostitev pri vtiskovanju, nanokompozit, obdelava prahu

\section{INTRODUCTION}

Powder-processed aluminum alloys reinforced with $\mathrm{SiC}$ particles provide significantly enhanced properties over conventional monolithic materials, such as higher specific modulus, strength and thermal stability. They are widely utilized in the aerospace and automobile industry as ground vehicle brake rotors, or combustion engine components. ${ }^{1-3}$ For the goal of investigating the creep properties, methods such as uniaxial (tension and compression), impression and relaxation are often used. ${ }^{4-8}$ The stress relaxation test is the ideal method to investigate the creep behavior of soft materials. In such tests, specimens are subjected to impressions at a predetermined impression depth level, the cross head is arrested and the decrement in magnitude (supposed depth) as a function of time is recorded. ${ }^{5,6,8}$ The stress-relaxation test has the advantages of simplicity and speed over the conventional creep test. ${ }^{5,6}$ There have been many studies evaluating the stress exponent and activation energy of creep mechanisms in different alloys employing various techniques. ${ }^{4-8}$ Furthermore, in different studies, the uniaxial creep properties of Al-SiC with micron sized reinforcements have been examined, ${ }^{9-13}$ but the effect of nanosized reinforcement and the evaluation of the steady state creep rate with compression and impression relaxation methods have not been investigated. Therefore, this paper aims at investigating the steady state creep rate of $\mathrm{Al}$ with $\mathrm{SiC}$ reinforcement (nanoparticles) by compression and impression relaxation tests. This approach is used to determine the correspondence of the creep results obtained through these different approaches. It is worth highlighting that the novelty of the present research is the evidence of the relaxation creep theory in these materials. The creep behavior of these composites with different methods has provided an understanding of the actual characteristics of nanocomposite. Additionally, this research aims at exploring the creep rate to evaluate the fracture time, especially in industrial cases, with porosity, with non-destructive methods. 

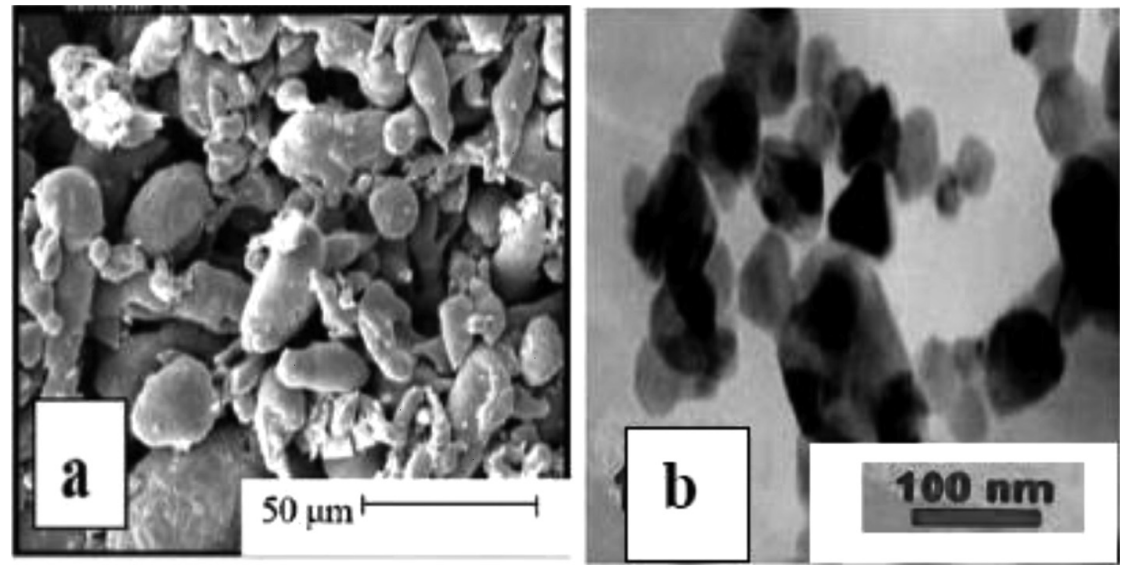

Figure 1: a) Morphology of as-received aluminum powders, b) TEM-micrograph of as-received nano-SiC powders Slika 1: a) Morfologija dobavljenih prahov Al, b) TEM-posnetek dobljenega SiC nanoprahu

\section{MATERIALS AND METHODS}

The base material used in the present experimental investigation are synthesized from: atomized Al powders with a purity of $99.5 \%$ and a particle size of less than 45 micron; reinforcing $\mathrm{SiC}$ powders with a purity of $99 \%$ and a particle size from $45 \mathrm{~nm}$ to $65 \mathrm{~nm}$ (Figure 1): and stearic acid with purity of $97.5 \%$ as a process control agent. Al-4\% of volume fractions $\mathrm{SiC}$ composites were made using a laboratory scale high-energy planetary ball mill at $260 \mathrm{~min}^{-1}$ with a $2 \%$ stearic acid mass fraction as a surface active agent and a ball to powder weight ratio of 15:1. Milling was carried out under an Ar atmosphere (99.999 \% purity). In order to avoid a significant temperature rise for the $4 \mathrm{~h}$ required to complete mixing, the ball milling process were stopped periodically for 20 $\mathrm{min}$, then resumed for $45 \mathrm{~min}$. The composite powders obtained by mechanical alloying, were gradually compacted uniaxially at room temperature using a cylindrical die-punch assembly (double end compaction type) to $620 \mathrm{MPa}$ with a Zwick 1496-2d. The compacted samples

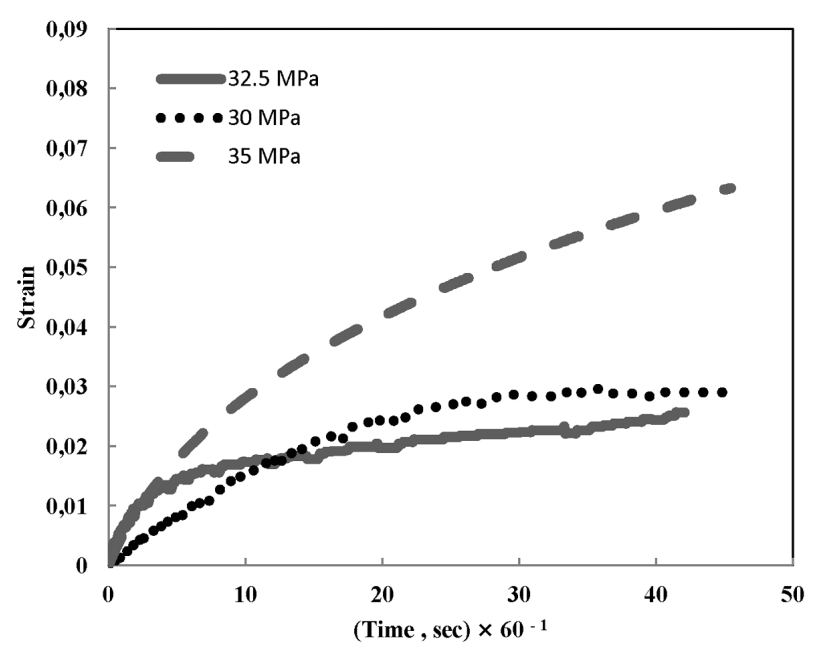

Figure 2: Compression strain as a function of time and compression stress

Slika 2: Skrček v odvisnosti od časa in napetosti pri stiskanju were sintered under Ar atmosphere (99.999\%) for $1 \mathrm{~h}$ at a temperature of $873 \mathrm{~K}$. The density of the composite was determined by the Archimedes' principle. Compression creep measurements were made on each sample (diameter and length of $10 \mathrm{~mm}$ ) using stresses in the range of 30-35 MPa with a Santam (STM 150) universal tensile testing machine.

Table 1 shows the sample specification (diameter of $10 \mathrm{~mm}$ and length of $5 \mathrm{~mm}$ ) for the impression tests. To measure the impression relaxation creep, a primary impression of $0.5 \mathrm{~mm}$ depth with a speed of $8.3 \times 10^{-4}$ $\mathrm{mm} \mathrm{s}^{-1}$ was used for all specimens. Having reached this indenter depth, the crosshead was stopped and the decrease in force with time was recorded. In another test the speed was increased to $8.3 \times 10^{-3} \mathrm{~mm} \mathrm{~s}^{-1}$ and indenter depths of $0.5 \mathrm{~mm}$ and $0.8 \mathrm{~mm}$ were selected. The stress relaxation results were also obtained.

Table 1: Porosity of samples used in impression tests

Tabela 1: Značilnosti uporabljenih vzorcev pri preizkusu vtiskovanja

\begin{tabular}{|c|c|}
\hline Sample & Porosity $(\%)$ \\
\hline 1 & 8.5 \\
\hline 2 & 13.6 \\
\hline 3 & 8.1 \\
\hline 4 & 10.5 \\
\hline 5 & 12.2 \\
\hline 6 & 11.4 \\
\hline 7 & 8.9 \\
\hline
\end{tabular}

\section{RESULTS AND DISCUSSION}

Figure 2 and Table 2 show the compression creep data. Figure 3 and Table 3 show the impression stress relaxation tests in different conditions. In Tables $\mathbf{4}$ and $\mathbf{5}$, the relationship between stress reduction in the impression-relaxation tests and creep rate in the uniaxial creep test is shown. 
Table 2: Compression steady state creep rate as a function of stress and porosity

Tabela 2: Hitrost lezenja pri stiskanju v odvisnosti od napetosti in poroznosti

\begin{tabular}{|c|c|c|c|}
\hline Sample & Porosity $(\%)$ & $\begin{array}{c}\sigma_{\text {Compression }} \\
(\mathrm{MPa})\end{array}$ & $\begin{array}{c}\text { Compression } \\
\text { creep rate }(1 / \mathrm{s})\end{array}$ \\
\hline 1 & 12 & 30 & $3 \times 10^{-6}$ \\
\hline 2 & 12 & 32.5 & $3 \times 10^{-6}$ \\
\hline 3 & 16 & 35 & $1 \times 10^{-5}$ \\
\hline
\end{tabular}

Table 3: Stress relaxation rate of composite samples as a function of indenter depth and enforcement rate

Tabela 3: Hitrost sproščanja kompozitnih vzorcev v odvisnosti od globine vtiska in hitrosti vtiskovanja

\begin{tabular}{|c|c|c|}
\hline Sample & $\begin{array}{c}\text { Indenter depth } \\
(\mathrm{mm}), \text { speed } \\
\left(\times 10^{3} \mathrm{~mm} \mathrm{~s}^{-1}\right)\end{array}$ & $\begin{array}{c}\mathrm{d} \sigma / \mathrm{d} t(\mathrm{MPa} / \mathrm{s}) \\
\times 10^{3}\end{array}$ \\
\hline 1 & $0.5,8.3$ & 7 \\
\hline 2 & $0.5,8.3$ & 0.9 \\
\hline 3 & $0.5,8.3$ & 3 \\
\hline 4 & $0.8,8.3$ & 4 \\
\hline 5 & $0.5,0.83$ & 6 \\
\hline 6 & $0.5,0.83$ & 3 \\
\hline 7 & $0.5,0.83$ & 3 \\
\hline
\end{tabular}

Table 4: Coefficient of stress relaxation and compression creep rates (C) $\left(\sigma_{\text {Compression }}=30,32.5 \mathrm{MPa}\right)$

Tabela 4: Koeficient sproščanja napetosti in hitrost lezenja pri stiskanju $(C)\left(\sigma_{\text {Compression }}=30,32,5 \mathrm{MPa}\right)$

\begin{tabular}{|c|c|c|c|}
\hline $\begin{array}{c}\text { Sample } \\
\text { (a) }\end{array}$ & $\begin{array}{c}\text { Indenter depth } \\
(\mathrm{mm}) \text {, speed } \\
\left(\times 10^{3} \mathrm{~mm} \mathrm{~s}^{-1}\right)\end{array}$ & $\begin{array}{c}C(\mathrm{MPa}) \\
\left\{\varepsilon^{\mathrm{o}}=(1 / C)(\mathrm{d} \sigma / \mathrm{d} t)\right\}\end{array}$ & Average $(C)$ \\
\hline 1 & $0.5,8.3$ & 2333 & \multirow{3}{*}{$\begin{array}{c}C=1211 \\
(\text { samples } \\
(1,2,3))\end{array}$} \\
\hline 2 & $0.5,8.3$ & 300 & \\
\hline 3 & $0.5,8.3$ & 1000 & \\
\hline 4 & $0.8,8.3$ & 1333 & $C=1333$ \\
\hline 5 & $0.5,0.83$ & 2000 & \multirow{3}{*}{$\begin{array}{l}C=1333 \\
(\text { samples } \\
(5,6,7))\end{array}$} \\
\hline 6 & $0.5,0.83$ & 1000 & \\
\hline 7 & $0.5,0.83$ & 1000 & \\
\hline
\end{tabular}

Table 5: Coefficient of stress relaxation and compression creep rates $(C)\left(\sigma_{\text {Compression }}=35 \mathrm{MPa}\right)$

Tabela 5: Koeficient relaksacije napetosti in hitrost lezenja pri stiskanju $(C)\left(\sigma_{\text {Compression }}=35 \mathrm{MPa}\right)$

\begin{tabular}{|c|c|c|c|}
\hline $\begin{array}{c}\text { Sample } \\
\text { (b) }\end{array}$ & $\begin{array}{l}\text { Indenter depth } \\
(\mathrm{mm}), \text { speed } \\
\left(\times 10^{3} \mathrm{~mm} \mathrm{~s}^{-1}\right)\end{array}$ & $\begin{array}{c}C(\mathrm{MPa}) \\
\left\{\varepsilon^{\mathrm{o}}=(1 / C)(\mathrm{d} \sigma / \mathrm{d} t)\right\}\end{array}$ & Average $(C)$ \\
\hline 1 & $0.5,8.3$ & 700 & \multirow{3}{*}{$\begin{array}{c}C=363 \\
(\text { samples } \\
(1,2,3))\end{array}$} \\
\hline 2 & $0.5,8.3$ & 90 & \\
\hline 3 & $0.5,8.3$ & 300 & \\
\hline 4 & $0.8,8.3$ & 400 & $C=400$ \\
\hline 5 & $0.5,0.83$ & 600 & \multirow{3}{*}{$\begin{array}{l}C=400 \\
(\text { samples } \\
(5,6,7))\end{array}$} \\
\hline 6 & $0.5,0.83$ & 300 & \\
\hline 7 & $0.5,0.83$ & 300 & \\
\hline
\end{tabular}

It is clear that the stress relaxation is a suitable criterion of the strain rate because of the constant strain (indenter depth) during the test. ${ }^{5,14}$ Figure 3 shows the positive effect of the enforcement rate of $0.83 \times 10^{-3}$ $\mathrm{mm} \mathrm{s}^{-1}$ and impression depth of $0.8 \mathrm{~mm}$ on recovery rate or viscoelastic coefficient decrease, relaxation $(\mathrm{d} \sigma / \mathrm{d} t)$ or

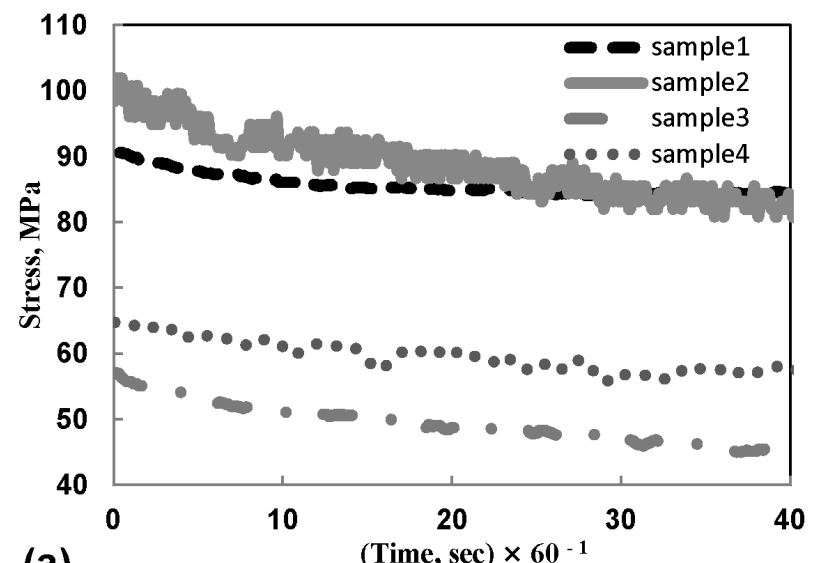

(a)

(Time, sec) $\times 60^{-1}$

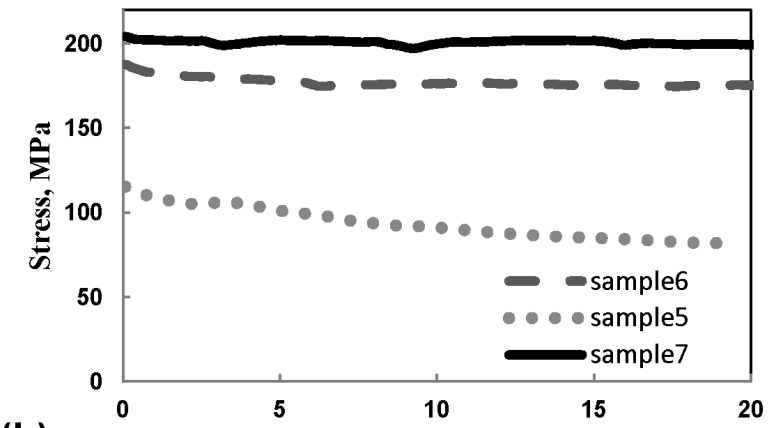

(b)

(Time, sec) $\times 60^{-1}$

Figure 3: Stress relaxation tests as a function of impression depth and strain rate: a) samples $1,2,3,4$, b) samples 5, 6, 7

Slika 3: Preizkus sprostitve v odvisnosti od globine vtiskovanja in hitrosti obremenjevanja: a) vzorci $1,2,3,4$, b) vzorci 5, 6,7

creep rate. In addition, the porosity and $\mathrm{SiC}$ distribution variations affect the movement of dislocations and threshold stress or internal friction stress. Experimental results on the creep behavior of $\mathrm{Al}$ composite with micron sized SiC by A. B. Pandey ${ }^{9}$ have emphasized the threshold stress increase with $\mathrm{SiC}$ content, interparticle spacing or particle size decrease. Thus, the creep resistance has been improved. Similar creep behavior has been reported in $\mathrm{Al}$ reinforced with nanoparticles which is the Orowan strengthening mechanism under the nano-reinforcement effect. ${ }^{15,16}$ In these studies the effect of oxide nanoparticles which leads to the reduction of dislocation movement has been clearly shown. Thus, in agreement with previous studies ${ }^{9,15-17}$, the reinforcing phase leads to creep resistance in the composites. Also the reinforcement distribution and particle size have been shown to affect the creep behavior of composites. ${ }^{9}, 18$ The novelty of this research in comparison with earlier work is in observation of the creep behavior of a composite using the impression-relaxation method. Initially, the speed of relaxation is high, as shown in Figure 3. Then the immobilized dislocations generate resistance and threshold stress. Consequently, the stress relaxation decreases until equilibrium between recovery and work hardening or the steady state condition (constant slope) is achieved. The stress relaxation behavior of materials leading to a steady state condition has been observed in 
other materials. ${ }^{19-21}$ Thus, in composites with $4 \%$ of volume fractions $\mathrm{SiC}$ (nano) produced by mechanical alloying, compacting with a compression force of 620 $\mathrm{MPa}$, and sintering at $873 \mathrm{~K}$, the primary stress relaxation rate decreases due to the creation of immobilized dislocations (pinning at the nano-reinforcement). Correspondingly, the existence of voids (depending on the indenter size) in the form of drops, or more relaxation, are observable in graphs. Considering Tables $\mathbf{4}$ and $\mathbf{5}$, the similarity of the coefficient of compression creep as well as the impression relaxation rates reveal minute differences of microstructure or SiC particles clustering. This issue has been proved in Tables $\mathbf{1}$ and $\mathbf{2}$ in which the samples' densities are shown. These minute differences are illustrated in the steady state rate fluctuations of the different samples' relaxation graphs. The impression relaxation rate increases with the increase of porosity and $\mathrm{SiC}$ clustering. This result shows that the impression relaxation test with this indenter size can be useful for obtaining the actual composite characteristics within a short test time.

In line with earlier studies, ${ }^{5,14}$ correlation of the relaxation and uniaxial creep data, and the strain rate $\left(\varepsilon^{\circ}\right)$ can be estimated using the stress relaxation rate $(d \sigma / d \mathrm{t})$ and the elastic modulus $(E)$ according to the following Equation (1):

$$
\varepsilon^{0}=-\frac{1}{E} \frac{\mathrm{d} \sigma}{\mathrm{d} t}
$$

According to Tables $\mathbf{4}$ and $\mathbf{5}$, the compression and impression methods are related to each other with the approximate constant $(C),(1000 \mathrm{MPa})$, even with changing indenter depth and enforcement speed, taking into account the role of porosity, Table 1 . The stability of the coefficient is decreased with the enforcement speed or strain rate (recovery increase) and the higher strength in samples 5, 6, and 7 is justified by the effect of the nano$\mathrm{SiC}$ in these composites. It means that the compression creep rate and impression stress relaxation in these composites are related by a constant of $1000(\mathrm{MPa})$, as given in Equation (1). It is useful for the determination of the composite fracture time using equations relating the strain rate and fracture time. The determination of the compression strain rate using the impression and impression stress relaxation methods, which rapidly yields the actual composite characteristics, helps in estimating the fracture time with the safety factor. In this research, on the basis of possible applications of this composite at high temperatures and compression forces (such as in a piston), the impression relaxation test was carried out at a temperature of $723 \mathrm{~K}$ and with high impression depths, e.g. $0.5 \mathrm{~mm}$ and $0.8 \mathrm{~mm}$, selected for industrial applications, and the relationship between compression rate and stress relaxation rate (coefficient) was calculated. Moreover, the stability of the coefficient $(C)$ over different experiments has been proved. In impression relaxation tests the value of the coefficient does not change with different indenter depth or enforcement speed, which is related to the $\mathrm{SiC}$ content. As Tables $\mathbf{4}$ and $\mathbf{5}$ show, the coefficient is affected only by the porosity and nano SiC distribution. This constant coefficient can be taken to be a function of the $\mathrm{SiC}$ content. These findings are suitable for the evaluation of fracture times and compression creep rate for research and industrial applications.

\section{CONCLUSIONS}

In the present study, a constant coefficient between impression relaxation rate and compression creep rate has been shown. The results indicate that in impression-relaxation tests, the impression depth and enforcement speed have no effect on the coefficient. The $\mathrm{SiC}$ reinforcement nanoparticles act as work-hardening particles. The porosity and the non-symmetrical distribution of $\mathrm{SiC}$ led to variations of the steady state relaxation rate or creep rate. The constant coefficient was a function of SiC content, porosity and the composite's elastic modulus.

\section{Acknowledgements}

The authors would sincerely like to acknowledge the Materials Engineering Department of Ferdowsi University of Mashhad for the experimental support of the research work.

\section{REFERENCES}

${ }^{1}$ M. Jahedi, B. Mani, S. Shakoorian, E. Pourkhorshid, M. Hossein Paydar, Deformation rate effect on the microstructure and mechanical properties of $\mathrm{Al}$ - SiCp composites consolidated by hot extrusion, Materials Science and Engineering A, 556 (2012), 23-30, doi:10.1016/j.msea.2012.06.054

${ }^{2} \mathrm{~S}$. Min, Effects of volume fraction of $\mathrm{SiC}$ particles on mechanical properties of $\mathrm{Al} / \mathrm{SiC}$ composites, Transactions of Nonferrous Metals Society of China, 19 (2009), 1400-1404, doi:10.1016/S1003-6326 (09)60040-6

${ }^{3}$ N. P. Cheng, S. M. Zeng, Z. Y. Liu, Preparation, microstructures and deformation behavior of $\mathrm{SiC}_{\mathrm{P}} / 6066 \mathrm{Al}$ composites produced by $\mathrm{PM}$ route, Journal of Materials Processing Technology, 202 (2008), 27-40, doi:10.1016/j.jmatprotec.2007.08.044

${ }^{4}$ D. Pan, I. Dutta, A mechanics-induced complication of impression creep and its solution: application to $\mathrm{Sn}-3.5 \mathrm{Ag}$ solder, Materials Science and Engineering A, 379 (2004), 154-163, doi:10.1016/ j.msea.2004.01.034

${ }^{5}$ Y. I. Jung, Y. N. Seol, B. K. Choi, J. Y. Park, Behavior of stress-relaxation and the estimation of creep in $\mathrm{Zr}-1.1 \mathrm{Nb}-0.05 \mathrm{Cu}$ alloy, Materials and Design, 42 (2012), 118-123, doi:10.1016/j.matdes. 2012.05.045

${ }^{6}$ L. Yinfeng, L. Zhonghua, Transverse creep and stress relaxation induced by interface diffusion in Unidirectional metal matrix composites, Composites Science and Technology, 72 (2012), 1608-1612, doi:10.1016/j.compscitech.2012.06.017

${ }^{7}$ S. Ansary, R. Mahmudi, M. J. Esfandyarpour, Creep of AZ31 Mg alloy: A comparison of impression and tensile behavior, Materials Science and Engineering A, 556 (2012), 9-14, doi:10.1016/j.msea. 2012.06.052

${ }^{8}$ R. G. Raghavender, O. P. Gupta, B. Pradhan, Application of stress relaxation testing in evaluation of creep strength of a tungsten- 


\section{Y. S. KAKHKI et al.: IMPRESSION RELAXATION AND CREEP BEHAVIOR OF Al/SiC NANOCOMPOSITE}

alloyed $10 \%$ Cr cast steel, International Journal of Pressure Vessels and Piping, 88 (2011), 65-74, doi:10.1016/j.ijpvp.2011.02.005

${ }^{9}$ A. B. Pandey, R. S. Mishra, Y. R. Mahajan, Steady state rate behavior of silicon carbide particulate reinforced aluminium composites, Acta Metallurgica Materialia, 40 (1992) 8, 2045-2052, doi:10.1016/0956-7151(92)90190-P

${ }^{10}$ F. Moreno Mario, J. R. Carlos, Oliver. González, Compression creep of PM aluminum matrix composites reinforced with $\mathrm{SiC}$ short fibres, Materials Science and Engineering A, 418 (2006), 172-181, doi:10.1016/j.msea.2005.11.035

${ }^{11}$ X. U. Fu-min, W. U. Lawrence, C. M. Han, G. W. Tan. Yi, Compression creep behavior of high volume fraction of $\mathrm{SiC}$ particles reinforced Al composite fabricated by pressureless infiltration, Chinese Journal of Aeronautics, 20 (2007), 115-119, doi:10.1016/ S1000-9361(07)60016-8

${ }^{12}$ K. Wakashima, T. Moriama, T. Mori, Steady state creep of a particulate $\mathrm{SiC} / 6061 \mathrm{Al}$ composite, Acta Materialia, 48 (2000), 891-901, doi:10.1016/S1359-6454(99)00386-9

${ }^{13}$ Z. Y. Ma, S. C. Tjong, Creep deformation characteristics of discontinuously reinforced aluminium-matrix Composites, Composites Science and Technology, 61 (2001), 771-786, doi:10.1016/S02663538(01)00018-5

${ }^{14}$ J. Gittus, Creep, Viscoelasticity and creep fracture in solids, Applied Science Publishers, England 1975

${ }^{15}$ J. Cadek, S. J. Zhu, K. Milick, Threshold creep behaviour of aluminium dispersion strengthened by fine alumina particles, Materials
Science and Engineering A, 252 (1998), 1-5, doi:10.1016/S09215093(98)00672-8

${ }^{16}$ Z. Lin, S. L. Chan, F. A. Mohamed, Effect of nano-scale particles on the creep behavior of $2014 \mathrm{Al}$, Materials Science and Engineering A, 394 (2005), 103-111, doi:10.1016/j.msea.2004.11.034

${ }^{17}$ W. J. Lee, S. K. Jo, I. M. Park, Y. H. Park, The effect of reinforcement clustering on the steady-state creep behaviours of discontinuous metal matrix composite: A possible origin of 'anomalously high' stress exponent, Materials Science and Engineering A, 528 (2011), 4564-4568, doi:10.1016/j.msea.2011.02.038

${ }^{18}$ S. P. Deshmukh, R. S. Mishra, K. L. Kendig, Creep behavior and threshold stress of an extruded $\mathrm{Al}-6 \mathrm{Mg}-2 \mathrm{Sc}-1 \mathrm{Zr}$ alloy, Materials Science and Engineering A, 381 (2004), 381-385, doi:10.1016/ j.msea.2004.05.025

${ }^{19}$ R. Mahmudi, A. R. Geranmayeh, H. Noori, H. Khanbareh, N. Jahangiri, A comparison of impression, indentation and impression-relaxation creep of lead-free $\mathrm{Sn}-9 \mathrm{Zn}$ and $\mathrm{Sn}-8 \mathrm{Zn}-3 \mathrm{Bi}$ solders at room temperature, Journal of Materials Science - Materials in Electronics, 20 (2009), 312-318, doi:10.1007/s10854-008-9726-x

${ }^{20}$ L. I. Trusove, T. P. Khvostantseva, Solov'ev and V. A Mel'nikova, Stress relaxation following heating of nanocrystalline nickel, Nanostuctured Materials, 4 (1994) 7, 803-813, doi:10.1016/0965-9773 (94)90086-8

${ }^{21}$ S. N. G. Chu, J. C. M. Li, Localized Stress Relaxation By Impression Testing, Materials Science and Engineering A, 45 (1980), 167-171, doi:10.1016/0025-5416(80)90222-0 